\title{
Synthesis, Structure Analysis and Antibacterial Activity of New Potent Sulfonamide Derivatives
}

\author{
Abdulhakeem Alsughayer ${ }^{1}$, Abdel-Zaher A. Elassar ${ }^{2,3}$, Seham Mustafa $^{1}$, Fakhreia Al Sagheer ${ }^{2}$ \\ ${ }^{1}$ Pharmaceutical Science Department, College of Health Science, The Public Authority for Applied Education and Training, Adai- \\ liyah, Kuwait; ${ }^{2}$ Chemistry Department, Faculty of Science, Kuwait University, Kuwait City, Kuwait; ${ }^{3}$ Chemistry Department, Facul- \\ ty of Science, Helwan University, Cairo, Egypt. \\ E-mail: aelassar@yahoo.com
}

Received October $6^{\text {th }}, 2010$; revised January $9^{\text {th }}, 2011$; accepted January $10^{\text {th }}, 2011$.

\begin{abstract}
Modification of sulfonamide drug using different principles of chemical reactions was investigated. These reactions involve the condensation of an amino group with triethyl orthoformate and dimethylformamide dimethyl acetal. Ability of sulfa to condense with active keto compounds, like ethyl pyruvate and piprazine carboxyaldehye was studied. Alkylation of sulfa with different chloro derivatives was also reported. The structure of the isolated compound was elucidated and confirmed using elemental analysis and spectral data. The bioactivity of the obtained compounds was investigated against different gram positive and gram negative bacteria. The study reveals that most of the modified drugs show high to moderate antibacterial activity.
\end{abstract}

Keywords: Sulfonamide, Sulfa Drug, Gram Positive, Gram Negative Bacteria

\section{Introduction}

The demand for novel chemotherapeutic antibacterial remains attractive in the field of medicinal chemistry. The discovery of sulfonamides as antibacterial in the early 30 s was the beginning of the most fascinating era of chemotherapeutic agents [1-4]. Since the introduction of prontosil over 70 years ago, sulfa drugs have been widely used to treat a broad spectrum of microbial diseases [5]. However, due to the rapid emergence of sulfonamide resistance organisms and the development of more potent drugs have limited their clinical use. The sulfonamide group is considered as a pharmacophore which is present in a number of biologically active molecules, particularly in antimicrobial agents [6-10]. In addition, numerous sulfonamide derivatives have been reported as carbonic anhydrase inhibitors [11-15], anticancer [16], and anti-inflammatory agents [17]. Some organisms are resistant to all approved antibiotics and can only be treated with experimental and potentially toxic drugs. Therefore, there is an overwhelming need to develop more effective antibacterial agents to treat infections caused by antibiotic resistant bacterial pathogens. Sulfonamides exert their effect by targeting on dihydropteroate synthase (DHPS) enzyme, which catalyzes folic acid pathway in bacteria and some eukaryotic cells [18] but is not present in human cells [19]. This is the basis for the selective effect of sulfonamides on bacteria and for their broad spectrum of antibacterial activity. Since sulfanilamide first came into use, different derivatives have appeared on the market. Chemically modified sulfanilamide is prepared to achieve more effective antibacterial activity, wider spectrum of microorganisms affected, or more prolonged action. Because of their low cost they are still used in many parts of the world. The substances are still used to treat some urinary tract infections, leprosy, and in combination with other drugs, fungal diseases such as toxoplasmosis. The pharmaceutical industry has responded with new classes of drugs, thus a great insight to search for potential pharmacologically active sulfanilamide and its derivatives is still of interesting.

This study deals with the synthesis of $N$-substituted sulfonamide derivatives. The structure was established and confirmed using elemental analysis and spectral data e.g. IR, ${ }^{1} \mathrm{H}$ NMR, ${ }^{13} \mathrm{C}$ NMR and MS spectra. Biological activity of the synthesized compounds against gram positive and gram negative bacteria has been investigated.

\section{Materials and Methods}

Sulfanilamide, triethyl orthoformate, ethyl pyruvate, 3chloro-2,4-pentanedione, dimethylformamide dimethylacetal (DMFDMA), piprazinecarboxyaldehyde, chloro- 
acetonitrile and chloroacetone (aldrich, milwaukee, wi) were used as received. All other chemicals were reagent grade and were used without further purification.

\subsection{Elemental Analysis and Physical Measurements}

All melting points are uncorrected. IR spectra were recorded in $\mathrm{KBr}$ with a IR spectrophotometer Shimadzu 408. ${ }^{1} \mathrm{H}$ NMR and ${ }^{13} \mathrm{C}$ NMR spectra were recorded on Varian EM-390 MHz spectrometer using TMS as an internal reference with the chemical shifts expressed as $\delta$ ppm. Mass spectra were measured on a Shimadzu GCMS-QP 1000 Ex mass spectrometer. Microanalytical data were obtained from the ANALAB Unit at chemistry department, Kuwait University.

2.2. Synthesis of $N, N$-(4-sulfonamido) formamidine (2b); of $N$, $N$-Bis (4-sulfonamido) formamidine (3); Ethyl $N$-(4-benzenesulfonaMido) -2-Iminopropanoate (4); 4-(Pipra- Zin-1-ylmethyleneamino) benzenesulfonamide (7); 4-(Cyanomethylamino) benzenesulfonamide (8); 4- (2Oxopropylamino) benzene-Sulfonamide (9);4(2,4-Dioxopentan-3-ylamino)benzenesulfonamide (10)

To a solution of $1(0.01 \mathrm{~mol})$ in toluene $(20 \mathrm{ml})$ and DMF (10 ml) mixture, dimethyl formaminde dimethyl acetal or triethyl orthoformate or ethyl pyruvate or piprazine carboxyaldehyde or chloroacetonitrile or 1-chloro2-propanone or 3-chloro-2,4-pentanedione $(0.01 \mathrm{~mol})$ was added. The reaction mixture was heated under reflux for $3 \mathrm{~h}$. The solvent was evaporated under vacuum and the solid product formed after cooling was collected by filtration, washed by ether and crystallized from proper solvent ( $c f$. Table 1).

\subsection{4-(3,5-Dimethyl-1 $H$-pyrazol-4-ylamino) benzenesulfonamide (11)}

To a solution of $\mathbf{1 0}(0.01 \mathrm{~mol})$ in DMF $(20 \mathrm{ml})$, hydrazine hydrate $(0.01 \mathrm{~mol})$ was added. The reaction mixture was heated under reflux for $3 \mathrm{~h}$. The solvent was evaporated under vacuum and the yellow solid product so formed after cooling was collected by filtration, washed by ether and crystallized from ethanol. Compound $\mathbf{1 1}$ was collected as pale brown crystal 66\% yield ( $c f$. Table 1).

\subsection{Drug Susceptibility Test}

The drugs were tested by disc-diffusion method. Diluted bacterial cultures $(100 \mathrm{~mL})$ were spread on sterile Mueller-Hinton agar plates, after which $8 \mathrm{~mm}$ diameter discs (sterile blank) impregnated with drug for testing (10-100 $\mathrm{mg}$ ) were placed on the plates. The plates were incubated for $24 \mathrm{~h}$ at $37^{\circ} \mathrm{C}$ under aerobic conditions and the diame- ter of the inhibition zone around each disc was then measured and recorded. If the drugs were found to be active in the disc diffusion test (inhibition zone $>10 \mathrm{~mm}$ ), they were further evaluated for determining minimum inhibitory concentration (MIC) values.

\subsection{Minimum Inhibitory Concentration (MIC)}

The drugs were screened for their antibacterial activity against E. coli, P. aeruginosa, B. subtilis and $S$. aureus. MIC was evaluated by turbidity method. A loop full of bacteria was inoculated in $100 \mathrm{~mL}$ of nutrient broth at $37^{\circ} \mathrm{C}$ for $20 \mathrm{~h}$ in a test-tube shaker at $150 \mathrm{rev} \mathrm{min}^{-1}$. The test compounds were prepared by dissolving in a minimal volume of DMSO and were serially diluted in Mueller-Hinton broth at concentrations in the range of $1-100$ $\mathrm{mg} / \mathrm{mL}$. The $24-\mathrm{h}$ bacterial cultures were then transferred into $10 \mathrm{~mL}$ of Muller-Hinton broth (control and test compounds) and incubated at $37^{\circ} \mathrm{C}$ for $24 \mathrm{~h}$. The growth of the bacteria was determined by measuring the turbidity after $24 \mathrm{~h}$. Thus, the MIC was generally read as the smallest concentration of drug in the series that prevents the development of visible growth of test organism. All the experiments were done in triplicate.

\subsection{Statistical Analysis}

The MIC value and modified drug susceptibility test were measured in triplicate. Statistical analysis of the MIC value was performed using the unpaired Student's $t$-test. Differences were considered significant when $P<$ 0.01 .

\section{Results and Discussion}

\subsection{Chemistry}

Sulfanilamide 1 reacted with triethyl orthoformate to give 4-(ethoxymethyleneamino) benzenesulfonamide 2a or $N, N^{\prime}$-bis (4-sulfonamido)formamidine $\mathbf{3}$ ( $c f$. scheme 1). Compound 2a was ruled out based on accurate mass $\mathrm{m} / \mathrm{z} 354.04$ which referred that the reaction took place with 1:2 molar ratios and was in agreement with the molecular formula $\mathrm{C}_{13} \mathrm{H}_{14} \mathrm{~N}_{4} \mathrm{O}_{4} \mathrm{~S}_{2}$ (cf. Table 1). While in the case of dimethyl formamide dimethyl acetal (DMFDMA) $N, N^{\prime}$-(4-sulfonamido)formamidine $\mathbf{2} \mathbf{b}$ was isolated. Further reaction of $\mathbf{2 b}$ with $\mathbf{1}$ gives $\mathbf{3}$. The structure of com-

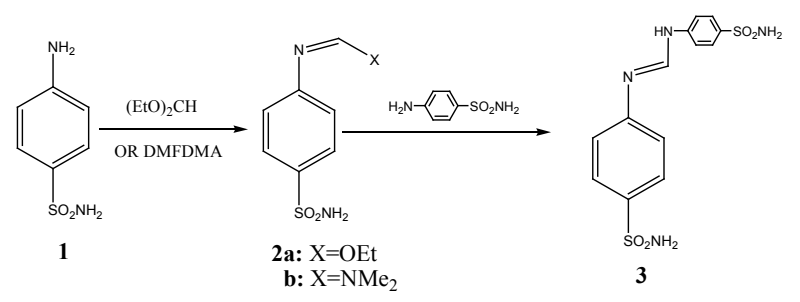

Scheme 1 
pound $\mathbf{3}$ was established based on elemental analysis and spectral data. The IR reveals the presence of amino groups and $\mathrm{NH}$ at 3461,3293 (assigned for $-\mathrm{NH}_{2}$ ), and $3203 \mathrm{~cm}^{-1}$ (assigned for $\mathrm{NH}$ ). The stretching vibrations assigned to the C-S linkage occur in 801 and $704 \mathrm{~cm}^{-1}$. Two characteristic bands for sulfonamide absorb strongly at 1295 and $1145 \mathrm{~cm}^{-1}$. In addition, ${ }^{1} \mathrm{H}$ NMR reveals the presence of imine proton at $\delta 6.74 \mathrm{ppm}$ (cf. Table 2, 3). Activity of amino group in sulfanilamide 1 towards active ketone compound was investigated. Thus, compound 1 reacted with ethyl pyruvate to give the condensation product, ethyl N-(4-benzesulfonamido)-2iminopropanoate 4 or 5 ( $c f$. scheme 2). The latter compound 5 was ruled out based on the spectral data. Thus, accurate mass assigned to compound 4 was found to be $\mathrm{m} / \mathrm{z} 270.07$ in agreement with the molecular formula $\mathrm{C}_{11} \mathrm{H}_{14} \mathrm{~N}_{2} \mathrm{O}_{4} \mathrm{~S}$. 1H NMR reveals the presence of the ethyl group as a triplet and a quartet at 1.71 and $4.21 \mathrm{ppm}$ with $\mathrm{J}$ value $6.8 \mathrm{~Hz}$, respectively ( $c f$. Table 3). Moreover, a characteristic band for ester carbonyl in IR was observed at $1738 \mathrm{~cm}^{-1}$. Sulfanilamide 1 reacted with piprazine carboxyaldehyde 6 to give the condensation product, 4-(piprazin-1-ylmethyleneamino) benzenesulfonamide, 7 (cf. scheme 3). The structure of the reaction product was believed to be formed through the addition of nucleophilic amino group to the electrophilic carbonyl carbon followed by loss of water molecule to give the isolated product 7. ${ }^{1} \mathrm{H}$ NMR reveals the presence of aromatic protons as dd at $\delta 7.46,7.43 \mathrm{ppm}$ with $J$ value $8.0 \mathrm{~Hz}$ and imine protons at $\delta 6.62 \mathrm{ppm}$. In addition, the methylene protons of piprazine ring appeared at $\delta 2.62$ and 2.57 ppm. ${ }^{13} \mathrm{C}$ NMR with ${ }^{1} \mathrm{H}$ NMR are confirmed the presence of $-\mathrm{CH}=\mathrm{N}-$ carbon and proton at $\delta 160.30 \mathrm{ppm}$ and 6.62 $\mathrm{ppm}$, respectively. Alkylation of sulfanilamide 1 with chloroacetonitrile, chloroacetone and 2-chloro-2,4-pentadione was created to yield $N$-alkyated derivatives 8-10, respectively (cf. scheme 4). The ac-curate mass of the alkylated products $8-10$ was $m / z 211.04,228.05$ and 270.07 , respectively. Compound 10 reacted with hydrazine hydrate to afford the $N$-pyrazolylsulfanilamide derivative $11 .{ }^{1} \mathrm{H}$ NMR showed bands at $\delta 7.46,7.40,6.61$ and $6.59 \mathrm{ppm}$ for aromatic protons with $\mathrm{J}$ value $8.0 \mathrm{~Hz}$. The pyrazole-H appeared at $\delta 7.30 \mathrm{ppm}$ with $J$ value 7.6 $\mathrm{Hz}$ other protons are shown in Table 2. Furthermore, ${ }^{13} \mathrm{C}$ NMR showed bands at $\delta 151.94,149.08,135.35,129.86$, $127.90,127.36$ and 126.66 assigned for aromatic carbons and pyrazole carbons. Two $\mathrm{sp}^{3}$ carbons were appeared at $\delta 26.68$ and $25.16 \mathrm{ppm}$.

Table 1. Data, accurate mass and elemental analysis of the prepared compounds.

\begin{tabular}{|c|c|c|c|c|c|c|c|}
\hline \multirow{2}{*}{ Compound No. } & \multirow{2}{*}{$\operatorname{Mp}\left({ }^{\circ} \mathrm{C}\right)$} & \multirow{2}{*}{ Solvent (yield \%) } & \multirow{2}{*}{ Accurate mass } & \multicolumn{4}{|c|}{ Elemental analysis Calcd/found (\%) } \\
\hline & & & & $\mathrm{C}$ & $\mathrm{H}$ & $\mathrm{N}$ & $\mathrm{S}$ \\
\hline $2 b$ & $159-160$ & DMF/EtOH $89 \%$ & $\mathrm{C}_{9} \mathrm{H}_{13} \mathrm{~N}_{3} \mathrm{O}_{2} \mathrm{~S} 227.07$ & $\begin{array}{l}47.56 \\
47.76\end{array}$ & $\begin{array}{l}5.77 \\
5.88\end{array}$ & $\begin{array}{l}18.49 \\
18.29\end{array}$ & $\begin{array}{l}14.11 \\
14.27\end{array}$ \\
\hline 3 & $273-274$ & DMF/EtOH $60 \%$ & $\mathrm{C}_{9} \mathrm{H}_{14} \mathrm{~N}_{4} \mathrm{O}_{4} \mathrm{~S} 2354.04$ & $\begin{array}{l}44.06 \\
44.07\end{array}$ & $\begin{array}{l}3.98 \\
4.20\end{array}$ & $\begin{array}{l}15.81 \\
15.88\end{array}$ & $\begin{array}{l}18.10 \\
17.96\end{array}$ \\
\hline 4 & $142-144$ & EtOH $73 \%$ & $\mathrm{C}_{11} \mathrm{H}_{14} \mathrm{~N}_{2} \mathrm{O}_{4} \mathrm{~S} 270.07$ & $\begin{array}{l}48.88 \\
48.80\end{array}$ & $\begin{array}{l}5.22 \\
5.22\end{array}$ & $\begin{array}{l}10.36 \\
10.54\end{array}$ & $\begin{array}{l}11.86 \\
11.81\end{array}$ \\
\hline 7 & $153-155$ & EtOH $60 \%$ & $\mathrm{C}_{11} \mathrm{H}_{16} \mathrm{~N}_{4} \mathrm{O}_{2} \mathrm{~S} 268.10$ & $\begin{array}{l}49.24 \\
49.22\end{array}$ & $\begin{array}{l}6.01 \\
5.99\end{array}$ & $\begin{array}{l}20.88 \\
21.01\end{array}$ & $\begin{array}{l}11.95 \\
12.11\end{array}$ \\
\hline 8 & $134-135$ & EtOH $78 \%$ & $\mathrm{C}_{8} \mathrm{H}_{9} \mathrm{~N}_{3} \mathrm{O}_{2} \mathrm{~S} 211.04$ & $\begin{array}{l}45.49 \\
45.51\end{array}$ & $\begin{array}{l}4.29 \\
4.31\end{array}$ & $\begin{array}{l}19.89 \\
19.88\end{array}$ & $\begin{array}{l}15.18 \\
15.21\end{array}$ \\
\hline 9 & $182-185$ & EtOH $76 \%$ & $\mathrm{C}_{9} \mathrm{H}_{12} \mathrm{~N}_{2} \mathrm{O}_{3} \mathrm{~S} 228.05$ & $\begin{array}{l}47.35 \\
47.34\end{array}$ & $\begin{array}{l}5.30 \\
5.30\end{array}$ & $\begin{array}{l}12.27 \\
12.31\end{array}$ & $\begin{array}{l}14.05 \\
13.97\end{array}$ \\
\hline 10 & $>250$ & DMF/EtOH $71 \%$ & $\mathrm{C}_{11} \mathrm{H}_{14} \mathrm{~N}_{2} \mathrm{O}_{4} \mathrm{~S} 270.07$ & $\begin{array}{l}48.88 \\
49.01\end{array}$ & $\begin{array}{l}5.22 \\
5.12\end{array}$ & $\begin{array}{l}10.36 \\
10.33\end{array}$ & $\begin{array}{l}11.86 \\
12.01\end{array}$ \\
\hline 11 & $179-180$ & $\mathrm{EtOH} 75 \%$ & $\mathrm{C}_{11} \mathrm{H}_{14} \mathrm{~N}_{4} \mathrm{O}_{2} \mathrm{~S} 266.08$ & $\begin{array}{l}49.61 \\
49.60 \\
\end{array}$ & $\begin{array}{l}5.30 \\
5.22 \\
\end{array}$ & $\begin{array}{l}21.04 \\
21.22 \\
\end{array}$ & $\begin{array}{l}12.04 \\
11.89 \\
\end{array}$ \\
\hline
\end{tabular}

Table 2. IR of the prepared compounds.

\begin{tabular}{cl}
\hline Cpd No. & \multicolumn{1}{c}{$\mathrm{IR}\left(\mathrm{cm}^{-1}\right)$} \\
\hline $2 \mathrm{~b}$ & $3451,3351\left(\mathrm{NH}_{2}\right) ; 1275,1135\left(-\mathrm{SO}_{2} \mathrm{NH}_{2}\right) ; 844,689(\mathrm{~S}-\mathrm{O})$ \\
3 & $3461,3293\left(\mathrm{NH}_{2}\right) ; 3203(\mathrm{NH}) ; 1295,1145\left(-\mathrm{SO}_{2} \mathrm{NH}_{2}\right) ; 801,704(\mathrm{~S}-\mathrm{O})$ \\
4 & $3463,3374\left(\mathrm{NH}_{2}\right) ; 1738(\mathrm{ester} \mathrm{CO}) ; 1629(\mathrm{C}=\mathrm{N}) ; 1311,1151\left(-\mathrm{SO}_{2} \mathrm{NH}_{2}\right) ; 829,722(\mathrm{~S}-\mathrm{O})$ \\
7 & $3471,3372\left(\mathrm{NH}_{2}\right) ; 3252(\mathrm{NH}) ; 1632(\mathrm{C}=\mathrm{N}) ; 1312,1145\left(-\mathrm{SO}_{2} \mathrm{NH}_{2}\right) ; 827,692(\mathrm{~S}-\mathrm{O})$ \\
8 & $3477,3382\left(\mathrm{NH}_{2}\right) ; 2200(\mathrm{CN}) ; 1310,1150\left(-\mathrm{SO}_{2} \mathrm{NH}_{2}\right) ; 825,694(\mathrm{~S}-\mathrm{O})$ \\
9 & $3477,3382\left(\mathrm{NH}_{2}\right) ; 3318(\mathrm{NH}) ; 1723(\mathrm{CO}) ; 1310,1150\left(-\mathrm{SO}_{2} \mathrm{NH}_{2}\right) ; 825,741(\mathrm{~S}-\mathrm{O})$ \\
10 & $3476,3373,3272\left(\mathrm{NH}_{2} \& \mathrm{NH}\right) ; 1698(\mathrm{CO}) ; 1295,1145\left(-\mathrm{SO}_{2} \mathrm{NH}_{2}\right) ; 801,704(\mathrm{~S}-\mathrm{O})$ \\
11 & $3473,3374,3265\left(\mathrm{NH}_{2}, \mathrm{NH}\right) ; 1318,1148\left(-\mathrm{SO}_{2} \mathrm{NH}_{2}\right) ; 840,686(\mathrm{~S}-\mathrm{O})$ \\
\hline
\end{tabular}


Table 3. ${ }^{1} \mathrm{H}$ NMR and ${ }^{13} \mathrm{C}$ NMR of the prepared compounds.

\begin{tabular}{|c|c|c|}
\hline Cpd No. & ${ }^{1} \mathrm{H}$ NMR $\delta(\mathrm{ppm})$ & ${ }^{13} \mathrm{C}$ NMR $\delta(\mathrm{ppm})$ \\
\hline $2 \mathrm{~b}$ & $\begin{array}{l}11.40,11.37\left(\text { br } 2 \mathrm{H}, \mathrm{NH}_{2}, \mathrm{D}_{2} \mathrm{O} \text {-exchange) }\right) ; 8.54-6.76(\mathrm{dd} \\
\left.4 \mathrm{H}, \mathrm{C}_{6} \mathrm{H}_{4}, \mathrm{~J}=8.8\right) ; 6.74(\mathrm{~s}, 1 \mathrm{H}, \mathrm{CH}=) 2.75,2.74(\mathrm{~s}, 6 \mathrm{H}, 2 \mathrm{Me})\end{array}$ & $\begin{array}{l}\text { 162.35(imine carbon); 157.96, 141.71, 128.07, 127.27, } \\
121.26,121.13 \text { (aromatic carbons) }\end{array}$ \\
\hline 3 & $\begin{array}{l}11.38\left(\mathrm{~d}, 1 \mathrm{H}, \mathrm{NH}, \mathrm{D}_{2} \mathrm{O} \text {-exchange }\right) ; 7.88,7.77\left(\mathrm{br}, 4 \mathrm{H}, 2 \mathrm{NH}_{2} \text {, }\right. \\
\mathrm{D}_{2} \mathrm{O} \text {-exchange); } 8.52-7.30\left(\mathrm{~m}, 8 \mathrm{H}, 2 \mathrm{C}_{6} \mathrm{H}_{4}\right) ; 6.74(\mathrm{~d}, 1 \mathrm{H}, \\
-\mathrm{CH}=\mathrm{N}, \mathrm{J}=7.6 \mathrm{~Hz})\end{array}$ & $\begin{array}{l}162.38 \text { (imine carbon); } 158.03,155.75,140.91,140.85 \\
\text { (C and } \mathrm{C} 4 \text { in two benzene rings); } 121.27,121.34, \\
128.88,128.78 \text { (other aromatic-C). }\end{array}$ \\
\hline 4 & $\begin{array}{l}9.00\left(\mathrm{br}, 2 \mathrm{H}, \mathrm{NH}_{2}, \mathrm{D}_{2} \mathrm{O} \text {-exchange }\right) ; 7.95-6.57\left(\mathrm{dd}, 4 \mathrm{H}, \mathrm{C}_{6} \mathrm{H}_{4}\right. \\
\mathrm{J}=8.8) ; 4.21\left(\mathrm{q}, 2 \mathrm{H}, \mathrm{CH}_{2}, \mathrm{~J}=6.8 \mathrm{~Hz}\right) ; 1.71(\mathrm{t}, 3 \mathrm{H}, \mathrm{Me}, \mathrm{J}=6.8 \\
\mathrm{Hz})\end{array}$ & $\begin{array}{l}163.45(\mathrm{CO}) ; 161.12 \text { (imine carbon); } 152.36,138.42, \\
\text { 128.01, } 123.29 \text { (aromatic carbons); } 61.24\left(\mathrm{CH}_{2}\right) ; 15.62, \\
14.35(2 \mathrm{Me}) .\end{array}$ \\
\hline 7 & $\begin{array}{l}8.00\left(\mathrm{~d}, 2 \mathrm{H}, \mathrm{NH}_{2}\right) ; 7.46,7.43\left(\mathrm{dd}, 4 \mathrm{H}, \mathrm{C}_{6} \mathrm{H}_{4}, \mathrm{~J}=8.4 \mathrm{~Hz}\right) ; 6.62 \\
(\mathrm{~s}, 1 \mathrm{H}, \mathrm{CH}=) ; 5.72(\mathrm{~s}, 1 \mathrm{H}, \mathrm{NH}) ; 2.62,2.57\left(\mathrm{tt}, 8 \mathrm{H}, 4 \mathrm{CH}_{2},\right. \\
\mathrm{J}=5.6 \mathrm{~Hz})\end{array}$ & $\begin{array}{l}160.3 \text { (imine carbon); 152.11, 131.01, 128.21, } 112.64 \\
\text { (aromatic carbons); 5.32, } 47.01 \text { (piprazine carbons). }\end{array}$ \\
\hline 8 & $\begin{array}{l}7.51,7.49\left(\mathrm{~d}, 2 \mathrm{H}, \mathrm{C}_{6} \mathrm{H}_{4}, \mathrm{~J}=8.0 \mathrm{~Hz}\right) ; 6.95(\mathrm{br}, 1 \mathrm{H}, \mathrm{NH}, \\
\mathrm{D}_{2} \mathrm{O} \text {-exchange); } 6.65,6.63(\mathrm{~d}, 2 \mathrm{H}, \mathrm{Ar}-\mathrm{H}, \mathrm{J}=8.0 \mathrm{~Hz}) ; 5.80(\mathrm{br} \text {, } \\
2 \mathrm{H}, \mathrm{NH}_{2}, \mathrm{D}_{2} \mathrm{O} \text {-exchange); } 2.86\left(\mathrm{~s}, 2 \mathrm{H}, \mathrm{CH}_{2}\right)\end{array}$ & $\begin{array}{l}151.88,132.70,127.44,112.53 \text { (aromatic carbons); } \\
129.90(\mathrm{CN}) ; 30.80\left(\mathrm{CH}_{2}\right) .\end{array}$ \\
\hline 9 & $\begin{array}{l}7.56\left(\mathrm{~d}, 2 \mathrm{H}, \mathrm{C}_{6} \mathrm{H}_{4}, \mathrm{~J}=8.4 \mathrm{~Hz}\right) ; 6.75\left(\mathrm{~d}, 2 \mathrm{H}, \mathrm{C}_{6} \mathrm{H}_{4}, \mathrm{~J}=8.8 \mathrm{~Hz}\right) \\
6.91\left(\mathrm{br}, 2 \mathrm{H}, \mathrm{NH}_{2}, \mathrm{D}_{2} \mathrm{O} \text {-exchange); } 8.02(\mathrm{br}, 1 \mathrm{H}, \mathrm{NH}\right. \\
\mathrm{D}_{2} \mathrm{O} \text {-exchange); } 4.45\left(\mathrm{~s}, 2 \mathrm{H}, \mathrm{CH}_{2}\right) ; 2.91(\mathrm{~s}, 3 \mathrm{H}, \mathrm{Me})\end{array}$ & $\begin{array}{l}162.45(\mathrm{CO}) ; 152.67,130.84,127.86,112.90 \text { (aromatic } \\
\text { carbons); } 35.49\left(\mathrm{CH}_{2}\right) ; 30.35(\mathrm{Me}) .\end{array}$ \\
\hline 10 & $\begin{array}{l}7.46\left(\mathrm{~d}, 2 \mathrm{H}, \mathrm{C}_{6} \mathrm{H}_{4}, \mathrm{~J}=8.4 \mathrm{~Hz}\right) ; 6.93\left(\mathrm{br}, 2 \mathrm{H}, \mathrm{NH}_{2}\right. \\
\mathrm{D}_{2} \mathrm{O} \text {-exchange); } 6.60\left(\mathrm{~d}, 2 \mathrm{H}, \mathrm{C}_{6} \mathrm{H}_{4}, \mathrm{~J}=8.0 \mathrm{~Hz}\right) ; 5.83(\mathrm{~s}, 1 \mathrm{H} \\
\mathrm{NH}, \mathrm{D}_{2} \mathrm{O} \text {-exchange); } 3.42(\mathrm{~s}, 1 \mathrm{H}, \mathrm{CH}) ; 2.50(\mathrm{~s}, 6 \mathrm{H}, 2 \mathrm{Me})\end{array}$ & $\begin{array}{l}169.00(\mathrm{CO}) ; 151.99,130.00,127.47,112.46 \text { (aromatic } \\
\text { carbons); } 85.00(\mathrm{CH}) ; 25.50(\mathrm{Me})\end{array}$ \\
\hline 11 & $\begin{array}{l}7.46,7.40\left(\mathrm{~d}, 2 \mathrm{H}, \mathrm{C}_{6} \mathrm{H}_{4}, \mathrm{~J}=8 \mathrm{~Hz}\right) ; 7.30(\mathrm{~d}, 1 \mathrm{H}, \text { pyrazole- } \mathrm{H}, \\
\mathrm{J}=7.6 \mathrm{~Hz}) ; 6.97\left(\mathrm{br}, 1 \mathrm{H}, \mathrm{NH}, \mathrm{D}_{2} \mathrm{O} \text {-exchange }\right) ; 6.61,6.59(\mathrm{~d}, \\
\left.2 \mathrm{H}, \mathrm{C}_{6} \mathrm{H}_{4}, \mathrm{~J}=8 \mathrm{~Hz}\right) ; 5.51\left(\mathrm{br}, 2 \mathrm{H}, \mathrm{NH}_{2}, \mathrm{D}_{2} \mathrm{O} \text {-exchange }\right) ; 1.67 \\
(\mathrm{~s}, 6 \mathrm{H}, 2 \mathrm{Me})\end{array}$ & $\begin{array}{l}151.94,149.08,135.35,129.86,127.90,127.36,126.66 \\
\text { (aromatic \& pyrazole carbons); } 26.68,25.16(2 \mathrm{Me})\end{array}$ \\
\hline
\end{tabular}

\subsection{Antimicrobial Activity}

Substitution on the sulfanilamide nitrogen is referred to as N1-substitution and N4-substitution on the 4-amino group as $N$-substitution. The therapeutically active derivatives are usually $N 1$-substitutes. The MIC values (average of triplicates) of the sulfanilamide and sulfanilamide derivatives are shown in Table 4 and Figures 1-5. It can be observed from Figures $\mathbf{1}$ and $\mathbf{2}$ that the antimicrobial results of compound $\mathbf{2 b}$ has high effect on S. Aureus and $E$. coli, while compound $\mathbf{9}$ and $\mathbf{4}$ have a low effect. In the case of E. coli compound $\mathbf{8}$ showed high effects as compared to compound 4 at low concentration $(10-40 \mathrm{mg}$ $\left.\mathrm{mL}^{-1}\right)$. In contrast at high concentration (70-100 mg) compound $\mathbf{4}$ showed greater effects than compound $\mathbf{8}$. Similar behavior was observed in the case of $E$. coli with compound (3 and 8) and (7 and 9). Severe effect was observed by compound 9 toward P. Aeruginosa and B. subtilis (cf. Figure 3 and 4). In general most compounds showed better effect with increase its concentration. In contrast to this, for compounds $\mathbf{2 b}$ and $\mathbf{7}$ at high concentration (more than $80 \mathrm{mg} \mathrm{mL}^{-1}$ ), the effect of compound 2b was more than compound 7 , while at low concentration (less than $80 \mathrm{mg} \mathrm{mL}^{-1}$ ) compound 7 showed greater effect than compound $\mathbf{2 b}$. Figure 5 represents the average zone of inhibition against sample number.
It shows that the effect of compound $\mathbf{2 a}$ on microorganism can be arranged as follows: E. coli $>S$. Aureus $>$ P. Aeruginosa $>$ B. subtilis (from highest to lowest); in the case of compound 3 the only observed effect is on $E$. coli followed by $S$. Aureus. Compound 4 showed severe

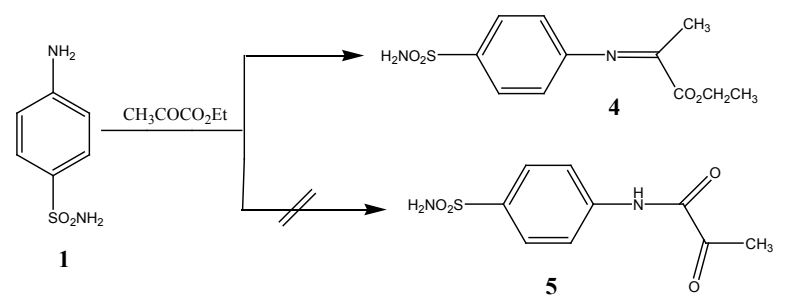

Scheme 2

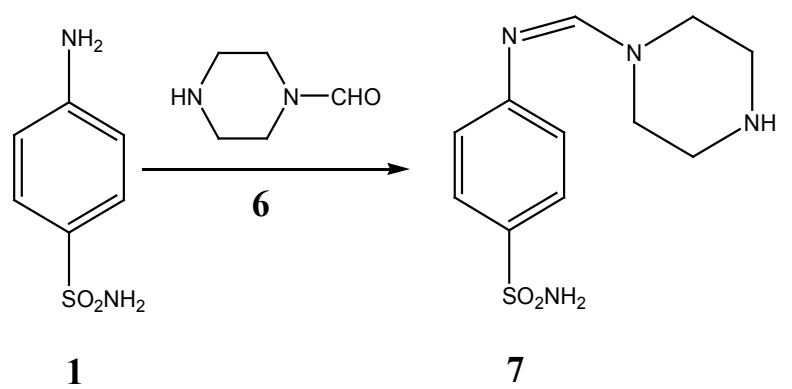

Scheme 3 


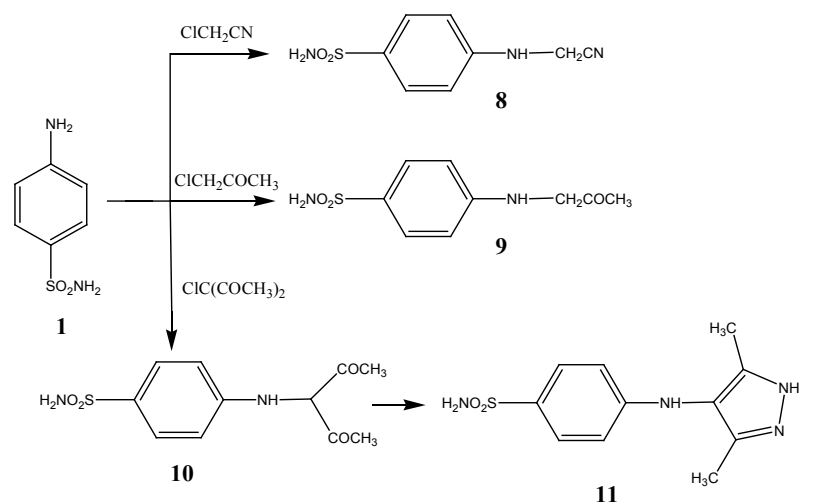

Scheme 4

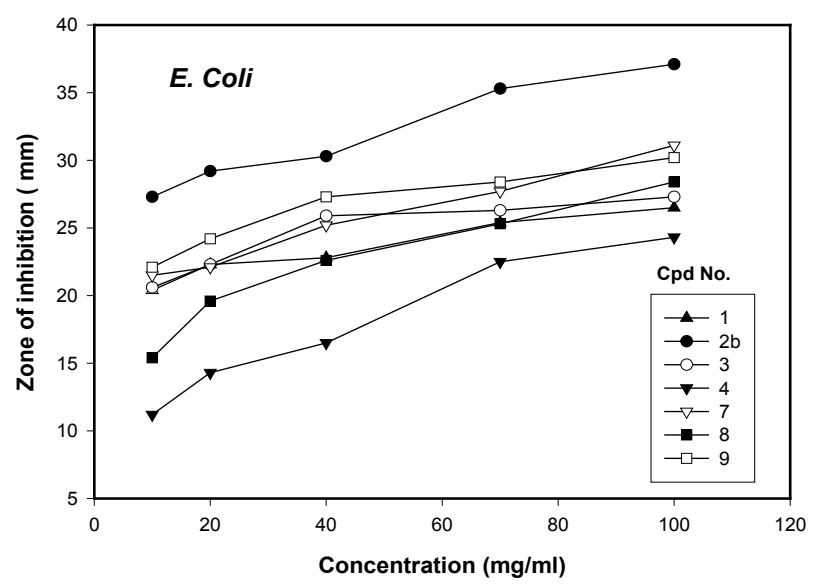

Figure 1. Effect of concentration of sulfa derivatives on $E$. Coli.

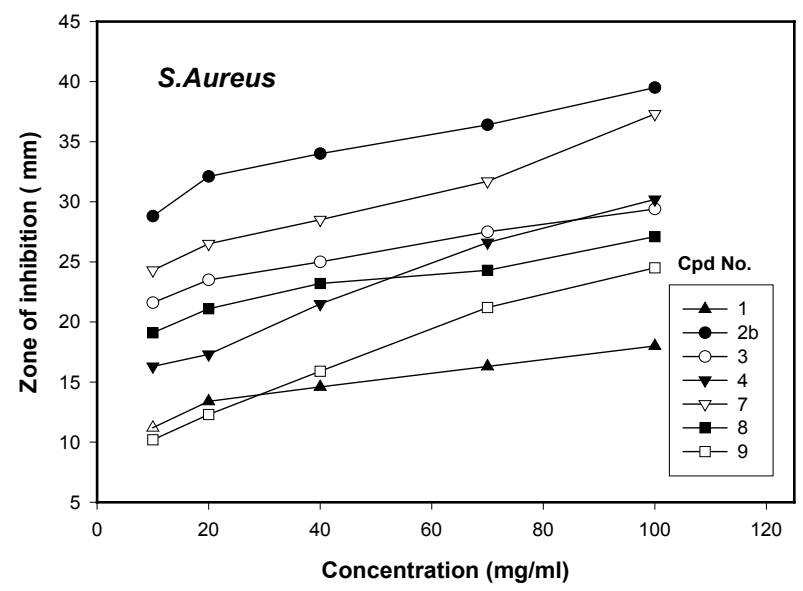

Figure 2. Effect of concentration of sulfa derivatives on $S$. Aureus.

effect with $S$. Aureus followed by $P$. Aeruginosa, B.subtilis and E. coli. Compound 7 showed a severe effect in the case of $S$. Aureus followed by $E$. Coli. Both $P$. Aeruginosa and B. subtilis showed approximately the same zone of inhibition. Compound $\mathbf{8}$ showed effect only

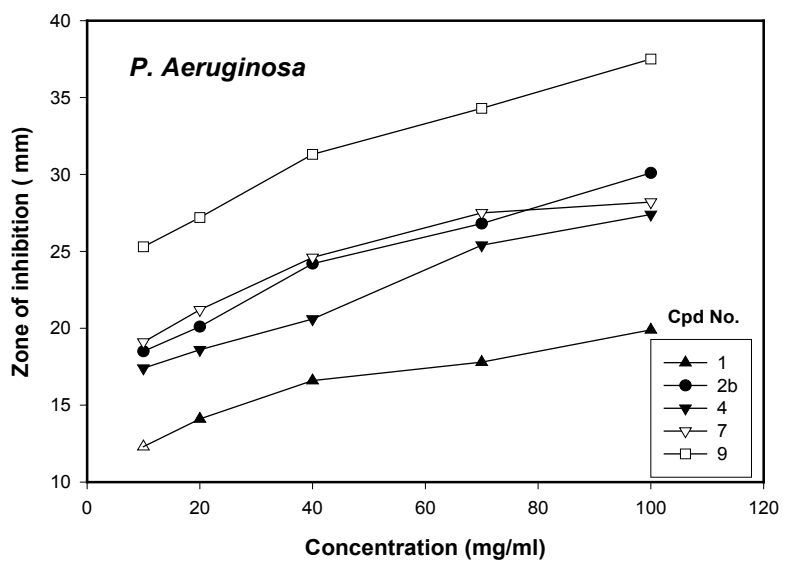

Figure 3. Effect of concentration of sulfa derivatives on $P$. Aeruginosa.

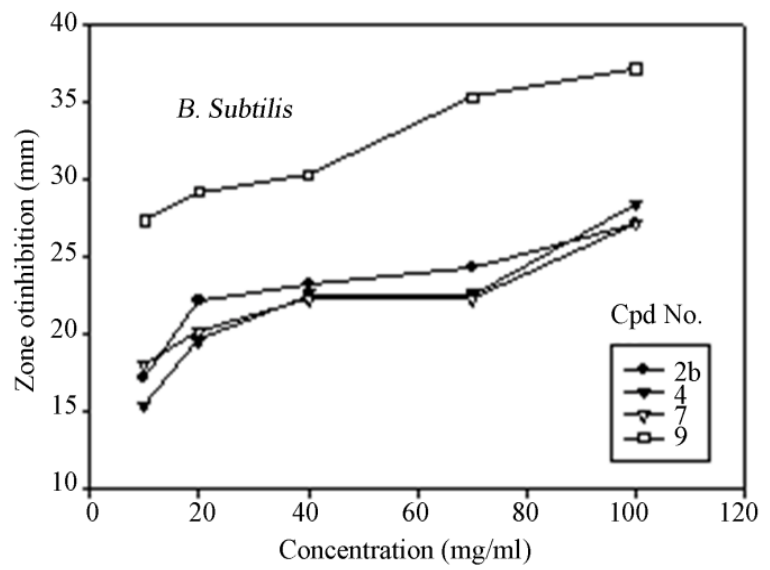

Figure 4. Effect of concentration of sulfa derivatives on $B$. Subtilis.

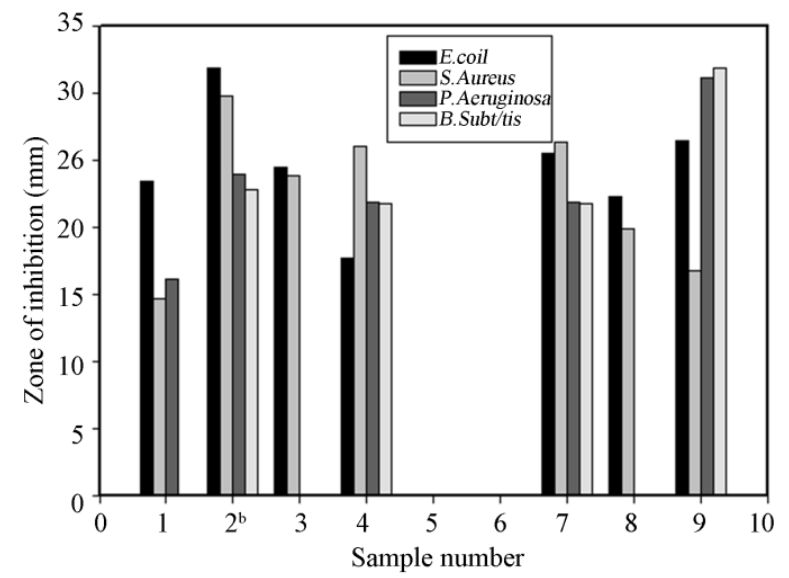

Figure 5. Zone of inhibition ( $\mathrm{mm})$ at different concentration against sample number. 
on E. coli and S. Aureus. Compound 9 showed a severe effect on $P$. Aeruginosa and B. subtilis. A moderate effect on $E$. coli and low effect was observed on S. Aureus.

\section{Acknowledgements}

The authors would like to acknowledge the Public Authority for Applied Education and Training for the provision of grant No. HS-07-01 and the authors would like also to acknowledge Kuwait University for the general facility projects grant Nos. GS 01/01 and GS 03/01.

\section{REFERENCES}

[1] N. Hen, M. Bialer, B. Wlodarczyk, R. H. Finnell and B. Yagen, "Syntheses and Evaluation of Anticonvulsant Profile and Teratogenicity of Novel Amide Derivatives of Branched Aliphatic Carboxylic Acids with 4-Aminobenzene sulfonamide," Journal Medical Chemistry, Vol. 53, No. 10, 2010, pp. 4177-4186. doi:10.1021/jm100170w

[2] F.Carta, A. Maresca, A. Scozzafava, D. Vullo and C. T. Supuran, "Carbonic Anhydrase Inhibitors. Diazenylbenzenesulfonamides are Potent and Selective Inhibitors of the Tumor-Associated Isozymes IX and XII over the Cytosolic Isoforms I and II," Bioorganic \& Medical Chemistry, 2009, Vol. 17, No.20, 7093-7099. doi:10.1016/j.bmc.2009.09.003

[3] K. Namba, X. Zheng, K. Motoshima, H. Kobayashi, A. Tai, E. Takahashi, K. Sasaki, K. Okamoto and H. Kakuta, "Design and Synthesis of Benzenesulfonanilides Active against Methicillin-Resistant Staphylococcus Aureus and Vancomycin-Resistant," Enterococcus Bioorganic \& Medical Chemistry, Vol. 16, No. 11, 2008, pp. 6131-6144.

[4] P. Joseph, F. Turtaut, S. Ouahrani-Bettache, J. L. Montero, I. Nishimori, T. Minakuchi, D. Vullo, A. Scozzafava, S. Kohler, J.-Y. Winum and C. T. Supuran. "Cloning, Characterization, and Inhibition Studies of a $\beta$-Carbonic Anhydrase from Brucella suis," Journal Medical Chemistry, 2010, Vol. 53, No. 5, pp 2277-2285. doi:10.1021/jm901855h

[5] B. L. Wilkinson, L. F. Bornaghi, A. D. Wright, T. A. Houston and S. A. Poulsen, "Anti-Mycobacterial Activity of a Bis-Sulfonamide," Bioorganic \& Medical Chemistry Letter, Vol. 17, No. 5, 2007, pp. 1355-1357. doi:10.1016/j.bmcl.2006.11.079

[6] B. G. Katzung, "Basic and Clinical Pharmacology," 6th Edition, University of California, San Francisco, 1995.

[7] S. Joshi and N. Khosla, "QSAR Study on Anti Bacterial Activity of Sulfonamides and Derived Mannich Bases," Bioorganic Medical Chemistry Letter, Vol. 13, No. 21, 2003, pp. 3747-3751. doi:10.1016/j.bmcl.2003.08.017

[8] S. Joshi, N. Khosla and P. Tiwari, "In Vitro Study of Some Medicinally Important Mannich Bases Derived from an Antitubercular Agent," Bioorganic \& Medical Chemistry, Vol. 12, No. 3, 2004, pp. 571-576. doi:10.1016/j.bmc.2003.11.001

[9] N. Anand, "Sulfonamides and Sulfones," In: M. E. Wolff, Ed., Burger's Medicinal Chemistry and Drug Discovery, John Wiley \& Sons, Inc., New York, 1996, pp. 527-573.
[10] A. Kamal, M. N. A. Khan, K. S. Reddy, K. Rohini, G. N. Sastry, B. Sateesh and B. Sridhar, "Synthesis, Structure Analysis and Antibacterial Activity of Some Novel 10-Substituted 2-(4-Piperidyl/Phenyl) -5, 5-Dioxo [1,2,4] triazolo $[1,5 \mathrm{~b}][1,2,4]$ Benzothiadiazine Derivatives," Bioorganic \& Medical Chemistry Letter, Vol. 17, 2007, pp. 5400-5405. doi:10.1016/j.bmcl.2007.07.043

[11] S. Zimmerman, A. Innocenti, A. Casini, J. G. Ferry, A. Scozzafava and C. T. Supuran, "Carbonic Anhydrase Inhibitors. Inhibition of the Prokaryotic Beta and GammaClass Enzymes from Archaea with Sulfonamides," Bioorganic \& Medical Chemistry Letter, Vol. 14, 2004, pp. 6001-6006. doi:10.1016/j.bmcl.2004.09.085

[12] V. Garaj, L. Puccetti, G. Fasolis, J-Y. Winum, J-L. Montero, A. Scozzafava, D. Vullo, A. Innocentia and C. T. Supurana, "Carbonic Anhydrase Inhibitors: Synthesis and Inhibition of Cytosolic/Tumor-Associated Carbonic Anhydrase Isozymes I, Ii, and Ix with Sulfonamides Incorporating 1,2,4-Triazine Moieties," Bioorganic Medical Chemistry Letter, Vol. 14, 2004, pp. 5427-5433. doi:10.1016/j.bmcl.2004.07.087

[13] L. Puccetti, G. Fasolis, D. Vullo, Z. H. Chohan, A. Scozzafavab and C. T. Supuranb, "Carbonic Anhydrase Inhibitors. Inhibition of Cytosolic/Tumor-Associated Carbonic Anhydrase Isozymes I, II, IX, and XII with Schiff Bases Incorporating Chromone and Aromatic Sulfonamide Moieties, and Their Zinc Complexes," Bioorganic \& Medical Chemistry Letter, Vol. 15, 2005, pp. 3096-3101. doi:10.1016/j.bmcl.2005.04.055

[14] J. M. Lehtonen, S. Parkkila, D. Vullo, A. Casini, A. Scozzafavac and C. T. Supuranc, "Carbonic Anhydrase Inhibitors. Inhibition of Cytosolic Isozyme XIII with Aromatic and Heterocyclic Sulfonamides: A Novel Target for the Drug Design," Bioorganic\& Medical Chemistry Letter, Vol. 14, 2004, pp. 3757-3762. doi:10.1016/j.bmcl.2004.04.106

[15] O. Güzel, A. Innocenti, A. Scozzafava, A. Salman and C. T. Supuran, "Carbonic Anhydrase Inhibitors. Phenacetyl-, Pyridylacetyl- and Thienylacetyl-Substituted Aromatic Sulfonamides Act as Potent and Selective Isoform Vii Inhibitors," Bioorganic \& Medical Chemistry Letter, Vol. 19, 2009, pp. 3170-3173. doi:10.1016/j.bmcl.2009.04.123

[16] A. Scozzafava, T. Owa, A. Mastrolorenzo and C. T. Supuran, "Anticancer and Antiviral Sulfonamides," Current Medical Chemistry, Vol. 10, No. 11, 2003, pp. 925-953. doi:10.2174/0929867033457647

[17] A. Weber, A. Casini, A. Heine, D. Kuhn, C. T. Supuran, A. Scozzafava and G. Kiebe, "Unexpected Nanomolar Inhibition of Carbonic Anhydrase by COX-2-Selective Celecoxib: New Pharmacological Opportunities Due to Related Binding Site Recognition," Journal of Medicinal Chemistry, Vol. 47, No.3, 2004, pp. 550-557. doi:10.1021/jm030912m

[18] G. M. Brown, "Biosynthesis of Folic Acid. II. Inhibition by Sulfonamides," Journal of Biological Chemistry, Vol. 237, No. 1962, pp. 536-540.

[19] P. Huovinen, L. Sundström, G. Swedberg, O. Skold and Antimicrob, "Agents Chemother Trimethoprim and Sulfonamide Resistance," Antimicrobiology Agents and Chemotherapy, Vol. 39, No.2, 1995, pp. 279-289. 